\title{
Connectivity of Actors and Diffusion of Ideas in HR Systems Configuration Process in Multinational Subsidiaries in Indonesia
}

\author{
Neil Semuel Rupidara \\ Faculty of Economics and Business, Universitas Kristen Satya Wacana, Salatiga, Jl. Diponegoro 52-60, Salatiga 50711
}

\begin{tabular}{l}
\hline A R T I C L E I N F O \\
\hline Keywords: \\
Connectivity of actors, \\
diffusion of ideas, \\
HR systems, \\
Indonesia, \\
isomorphism, \\
multinational subsidiaries \\
Kata Kunci: \\
Keterhubungan aktor-aktor, \\
difusi gagasan, \\
sistem MSDM, \\
Indonesia, \\
isomorfisme, \\
subsidiari perusahaan multinasional
\end{tabular}

Corresponding author: nrupidara@staff.uksw.edu

\author{
A B S T R A C T
}

Human Resource (HR) literature tends to overlook the process of HR systems configuration. Researching the process, this article particularly examines the phenomenon of connectivity and the diffusion of ideas among HR actors and other actors outside companies. Three case studies of multinational subsidiaries in Indonesia were conducted. Data were collected through interviews, observations, and corporate documents and were analyzed using a modified-grounded approach. The findings show similarities among elements of HR systems across the cases, showing connectivity of ideas and actors in the configuration process. The ideas constituting the HR systems within each company were adopted through a variety of channels of diffusion. This article proposes a typology of connectivity of actors that enables the diffusion and adoption of ideas across companies.

\section{SARI PATI}

Proses konfigurasi sistem Manajemen Sumber Daya Manusia (MSDM) cenderung tidak mendapatkan perhatian yang memadai dalam literatur MSDM. Meneliti tentang proses tersebut, artikel ini secara khusus menelaah fenomena keterhubungan dan difusi ide-ide di antara aktoraktor pengelola MSDM di dalam perusahaan dengan aktor-aktor relevan lainnya. Tiga studi kasus pada subsidiari perusahaan multinasional yang beroperasi di Indonesia dilakukan. Data dikumpulkan melalui wawancara, observasi, dan kajian atas dokumen perusahaan dan dianalisis dengan pendekatan grounded theory yang dimodifikasi. Temuan lapangan menunjukkan adanya kemiripan-kemiripan antar elemen-elemen sistem MSDM pada perusahaan-perusahaan yang distudikan, menunjukkan kesalingterhubungan gagasan-gagasan dan aktor-aktor dalam proses konfigurasi. Gagasan-gagasan pembentuk sistem MSDM di setiap perusahaan diadopsi melalui berbagai jalur difusi. Artikel ini mengembangkan sebuah tipologi keterhubungan antar aktor yang memungkinkan terdifusi dan diadopsinya gagasangagasan lintas perusahaan. 


\section{INTRODUCTION}

Understanding HR processes is as important as our knowledge of HR contents that is dominating HR research (Brewster, Mayrhofer, \& Smale, 2016; Sanders \& Yang, 2016). Bowen and Ostroff (2004) and Paauwe (2004) have made a call for greater attention towards a process-oriented HRM. Different authors built theoretical arguments, and accumulated empirical evidence around HR processes (e.g. Hauff, Alewell, \& Hansen, 2016; Rupidara \& McGraw, 2011; Sanders, Shipton, \& Gomes, 2014; Smale, 2007; Sumelius, Bjorkman, Ehrnrooth, Makela, \& Smale, 2014). Despite an increasing accumulation of knowledge over the last two decades, this article argues that detailed understanding of various HR processes is still needed. This includes the understanding of the process how HR actors build HR systems within firms.

This article contributes to the HR process literature by particularly shifting the attention to a different perspective than what most HR process scholars have paid attention to in the past. Research on HR processes has primarily drawn attention to how HR systems work and affect firm performance, particularly on "the psychological processes through which employees attach meaning to HRM" (Sanders \& Yang, 2016, p. 1). The reason to pay attention to the configuration process is that all process aspects start from and depend on this process. A configuration process is defined here as the structuring of elements of HR systems, including adaptations, changes of elements of the systems across time (Rupidara \& McGraw, 2011). The process absorbs time and energy of HR actors, while unsuccessful configuration will be costly. It therefore needs considerable attention.

To understand how the configuration process is taking place, this article focuses on mechanisms that lead HR actors to take actions in building HR systems. This will explain how certain configuration of HR systems comes into being. Little attention has however been paid to this issue in HR literature, more specifically in multinational context. The specific context of foreign multinational subsidiaries operating in Indonesia is considered unique due to its transitional nature that highlights the co-existence of competing logics influencing HR actors during the process. In such an environment different ideas are diffused by or through different actors at different levels, used by the actors in HR systems configuration (e.g., Chow, 2004; Farndale \& Paauwe, 2007; Rupidara \& McGraw, 2011). In analysing the situation, this article pays particular attention to how connectivity of multiple actors within and/or beyond the HR field in Indonesia may play a role in the process, an aspect that is also neglected in HR process literature.

In analysing mechanisms involved in the configuration process, this article adopts an emerging micro-foundational view in organisational institutionalism (Powell \& Colyvas, 2008) and endorses it with Bourdieusian sociology of action (e.g. Grenfell, 2008). Powell \& Colyvas (2008: 277) argue, “...the development of microlevel explanations will give more depths to accounts of macro-level events and relationships." This paper particularly contends that varied and rich interactions among relevant actors in a field will foster the diffusion and adoption of HR policies or practices that lead to increasing similarities between firms. It thus attempts to respond to the call to provide more nuanced explanations of institutional mechanisms such as isomorphism (Campbell, 2004; Greenwood, Oliver, Rupidara \& Darby, 2017; Sahlin, \& Suddaby, 2008).

In presenting research findings, this article first presents theoretical underpinnings and methodological aspects of the study, followed by background information about the Indonesian business and institutional context. Second, evidence of similarities between HR systems across the case organisations is presented. Third, case descriptions are presented and the sources of ideas that are utilised by HR actors within each firm in developing HR systems for their organisations 
are identified. Finally, research findings are discussed and conclusion and recommendations are made.

\section{The Configuration of HR Systems and Isomorphic Mechanisms}

Research on HR systems enters a different phase as researchers paying attention to different process aspects (Monks and McMackin, 2001; Myloni, Harzing, \& Mirza, 2004; Rupidara \& McGraw, 2011; Sanders et al., 2014; Smale, 2008; Yahiaoui, 2014). Early research on the establishment of HR systems, particularly in a multinational subsidiary context, dealt with the transfer of HR practices from multinational headquarters to their subsidiaries (e.g. Beechler \& Yang, 1994; Tayeb, 1998). Smale (2007; 2008) enriched the transfer studies, revealing the complexity of transferring HR practices across borders. Myloni and colleagues (2004) examined the influence of cultural and institutional differences or the duality of host country and home country contexts in the process. Rupidara and McGraw (2011) depicted different actors at different levels interacted in the process, namely HR managers and related actors in consulting and educational organisations, also regulatory actors. Whereas later, Yahiaoui (2014) identified two processes of 1) diffusion as action sending HR practices from parent firms to subsidiaries and 2) adaptation as action of HR actors at subsidiaries to localize the practices.

This article argues for the centrality of the connectivity of actors in explaining the diffusion of HR ideas from one actor to the other in the configuration process. The connectivity of actors signifies the connectivity of ideas. Here some actors play the role of carriers of ideas (Zilber, 2002), taking ideas from one place and delivering them to other actors, which then turning them into local practices, with or without changing any attributes of the ideas adopted. HR systems configuration process thus involves the phenomenon of the travel of ideas (Czarniawska \& Joerges, 1996) across places and time, opens up for the possibility of similarities of features of organisations; in organisational structures or elements of HR systems. This well-known occurrence of institutional isomorphism has been central to organisational institutionalism (e.g. DiMaggio \& Powell, 1983, 1991; Scott, 2008), as there is increasing evidence of a degree of homogenisation across organisations.

In arguing for the centrality of actors and their connectivity in the process to configuring HR systems within firms, it is important to define the term "actor" in this study. In organisational studies particularly, isomorphism is usually explained as an act of organisations (DiMaggio \& Powell, 1983; Mizruchi \& Fein, 1999). This behaviour can only occur through the people representing their organisations. The concept 'actor' can therefore refer to either individual or organisation, although this article notably refers it to human actor, particularly HR actors within firms and their counterparts outside such as peer HR professionals and consultants. The 'connectivity of actors' thus refers to the connectivity of those actors. The human actors are however considered acting for their respective organisations. It therefore points to the embeddedness of individuals to their organisations.

In line with DiMaggio and Powell (1983), the isomorphic interactions observed in this study are situated within a specific context, namely an Indonesian HR field as an organisational field. An organisational field is an arena where actors interact. DiMaggio and Powell defined it as "those organizations, in the aggregate, who constitute a recognized area of institutional life: key suppliers, resource and product consumers, regulatory agencies, and other organizations that produce similar services or products" (pp. 64-65). Scott (2008) emphasised "the totality of relevant actors" as an important attribute of a field. This signals the existence of certain boundaries within which a collection of actors interacts one to the other. The boundaries may be an industrial or business sector, although this research refers it more as the 
boundary of a profession, comparable to accounting, law, or medicine professions (Greenwood, Suddaby \& Hinings, 2002; Reay \& Hinings, 2009). This encompasses multiple interactions among relevant actors as long as they connect to various aspects of HR as a professional field.

Here the work of Pierre Bourdieu is helpful as it provides a richer meaning in explaining relations dynamics within a field, including its relations with the actors inside and the relations among the actors themselves (Grenfell, 2008). In Bourdieu's view, a field is a social arena with its own rule or nature of the game in which social actors in their various social positions struggle for desirable ends in a relational way (Bourdieu, 1983; De Nooy, 2003; Martin, 2003). By describing a field as a "field of power," Bourdieu anticipated similarities across fields that indicate the exchanges of influence within and across fields through the role of actors. He used the concept of habitus to express the embeddedness of actors to signify the capabilities of actors in transforming a field. Habitus refers to the embodiment, which happens across time, of social structures into the minds and actions of social actors, by which the actors are enabled to attach meanings and give responses to their surrounding environment (Grenfell, 2008). Besides habitus, Bourdieu's concept of "capital," which refers to a specific position that an actor holds within the field, can further explain the degree of influence an actor has during engagements. This includes more dynamic, reciprocal interactions between actors and their habitus and fields, of agency and structures, subject, and object (Grenfell, 2008).

These concepts transcend the dichotomy of actors and institutions and encompass the idea that isomorphic actions are a result of rich interactions among actors and between actors and institutions across time. Bourdieu's viewpoint turns the meaning of actors as organisations into actors as individuals, as referred to in this study. Bourdieu's view also provides a basis for historical dimension in observing the interactions of actors, ideas, or knowledge within and across fields. In such a view, actions in the past have led to subsequent choices of action by the same and/or other actors in a particular field from time to time. This indicates the need for a methodological approach that can trace various past and present interactive experiences between actors that have resulted in adopting certain ideas into companies that later make up HR systems.

In taking the more dynamic view of interactions within a field, this article considers the possibility of a widening outreach of actors from one field to the other in seeking higher legitimate ideas. This process of widening outreach is understood as being facilitated also by institutional mechanisms. It can thus be described as widening institutional fields, noting that it is the interactions among actors inside or across fields that define the boundaries between fields. As actors can reach far into other fields, this implies the possibility of more influencing ideas being involved in the interactions in the "home" field from which actors originate. This further implies an increasing amount of complexity in the interacting processes and also in any effort to depict the dynamic interactions among the actors and of ideas.

Applying the possible widening of a field due to the increasing globalisation of ideas (Czarniawska \& Joerges, 1996), the study raises the possibility that actors' connectivity may extend beyond their existing organisational and geographical boundaries. The extended connectivity of actors may include other actors within and beyond the countries in which MNCs operate. As various actors may be involved in the networks, multiple sources or channels of HR ideas may consequently exist to facilitate the diffusion and adoption of ideas in organisations within a field. An individual actor who moves across organisational contexts across time brings different ideas or logics into and from the different contexts. This argument can imply changes of the actors' habitus (Grenfel, 2008) and thus the actions of actors in the fields in which 
they exist, including in HR in Indonesia where multinational subsidiaries operate.

Using this perspective in the process to configure HR systems within multinational subsidiaries, this article argues that sources influencing the process can be beyond the relationships of headquarters and subsidiaries of MNCs. It implies a need for perspective that exceeds the bipolar model of relationship between headquarters and their subsidiaries that was dominating IHRM and international management literature (Bartlett \& Ghoshal, 1991, 2000; Doz, Bartlett \& Prahalad, 1981; Schuler, Dowling \& De Cieri, 1993; Taylor, Beechler \& Napier, 1996). Pudelko and Harzing (2007, 2008) introduced a third dimension, called "the dominant effect" that opens up the possibility of dealing with the extended connectivity of actors beyond the boundaries of multinational parents and local institutional contexts.

Given the importance of the connectivity of actors, tracing and identification of actors within a network may provide insight into how and why isomorphism occurs within the context of HR systems configuration in multinational subsidiaries. As Galaskiewicz and Wasserman (1989, p. 455) argue, "Networks may also be a source of information and new ideas for organizational decision makers. By tapping those in their networks, managers learn about options and strategies that they themselves might adopt."

\section{Research Context: Indonesian Business and Institutional Environment}

Using organisational institutionalism as a theoretical framework, this study examines micro level decisions process taken by individual and/ or organisational actors in their relations to wider institutional logics and mechanisms. In so doing, it attempts to understand how institutionalised ideas with the HRM field in Indonesia influence the process. It is therefore important to understand the Indonesian business and institutional environment as the context of this study.
Prior to 1997, and particularly in the late 1980s to mid-1990s, Indonesia was acknowledged as one of the most promising emerging economies in Asia. As a country with the fourth largest population in the world, abundant natural resources and high economic growth (6-7 percent per annum), Indonesia was very attractive for foreign investment (Takii \& Ramstetter, 2005; Thee, 1991). The number and contribution of multinational companies operating in Indonesia was increasing (Takii \& Ramstetter, 2005). Indonesian business, however, was (and still is) dominated by small and medium scale business enterprises, which account for more than 99 percent of total enterprises (Tambunan, 2007). The remaining 1 percent major companies contributed about 40 percent of the total GDP (Tambunan, 2007; Timberg, 2000). These businesses included a number of Indonesian conglomerates, of which three were the previous majority owners of the selected case multinationals. There were significant gaps in the business performance of these two groups and therefore in their organisational or managerial capabilities (cf. Rupidara \& McGraw, 2008).

The buoyant economy could not escape the effect of the Asian monetary crisis in 1997. The Indonesian Rupiah currency rate fell against major foreign currencies, especially the US dollar, which hit the economy severely (Simandjuntak, 1999; Tarmidi, n.d.) and created political instability. This instability led to the demise of the long-established political regime of President Soeharto (Rupidara \& McGraw, 2010), and Indonesian conglomerates who had benefited from the regime had their business enterprises taken over by the incoming government.

The post-crisis economy of Indonesia evolved slowly but steadily through the efforts of governments in Era Reformasi to rebuild the national economy. Structural changes occurred in both government and business sectors, with changes in the regulative environment, including in labour relations (Manning \& Roesad, 2007; 
Rupidara \& McGraw, 2010) that affected HR policies and practices, particularly in the private sector. Law reforms adopted institutional logics that favoured market flexibility and clean, good governance to oversee the "new" economy in a more efficient way but corruption continues to be a big impediment to the Indonesian economy to this day (see e.g., Rupidara \& McGraw, 2010).

It has been argued that MNCs have played an increasingly important role in economic development in Indonesia (Takii \& Ramstetter, 2005). During the crisis, MNCs appeared to be cautious in their overseas operations, but they became more active in the crisis aftermath. Indonesian companies, including the case companies in this study, were taken over and turned into foreign affiliated companies. The spillover of technology and knowledge from MNCs in Indonesia to the Indonesian institutional context may account for the important role played by this particular group of companies (Rupidara \& McGraw, 2008; Takii \& Ramstetter, 2005).

\section{METHODS}

This study comprises case studies conducted at three foreign multinational subsidiaries operating in Indonesia (cf. Eisenhardt, 1989; Mabry, 2009; Stake, 1994; Stark \& Torrance, 2008; Yin, 1989). To study the complex but less understood process of configuration of HR systems in the multinational subsidiary context in general and in Indonesia in particular, case study is considered an appropriate approach (cf. Flyvbjerg, 2006). The MNCs all originated from respected local firms which later became foreign-affiliated companies. The changing ownership from local to foreign affiliation was considered important in identifying different sources of influence in the configuration of HR systems within the firms.

Albeit having some differences, the study considered similar attributes across the case organisations. First, all organisations operate under the same institutional environment of Indonesian
HR field that may exercise similar influences through certain institutional mechanisms that may produce similarity in elements of $\mathrm{HR}$ systems across organisations. Viral diffusion (see Greenwood et al., 2008) of legitimate HR ideas or practices may overcome organisational boundaries. If certain similarities exist, further investigation into possible causes may be required, including the connectivity of actors as a mechanism that may have helped diffusing $\mathrm{HR}$ ideas across the different organisations. Second, the shared characteristic of changing ownership and/or affiliation among the MNC subsidiaries indicates a connectivity to a possibly new source of ideas that may have an impact on the (re-) configuration of HR systems. This may include the connectivity to the new parent firms. Third, since all the multinational subsidiaries are joint-ventures with foreign majority, there is a possibility of more control from the MNCs' headquarters.

A fourth case of an Indonesian public authority was supplemented as a comparison. Similar to the three case multinationals, the national public organisation also experienced a radical identity change.Itturnedfromanorganisation characterised by high levels of government intervention into a more independent and professional organisation. Table 1 provides relevant information on the four case organisations.

The study comprises a period of ten days live in at each of the case organisations. During the live ins, data were collected through interviews (Czarniawska, 2004; Elliott, 2005; Flick, 2006; Riessman, 2008), informal talks, observations, and documentary studies. In-depth, narrative interviews were conducted with a total of 34 managers representing different $\mathrm{HR}$ and other relevant functions within their organisations. The number of interviewees in each firm differs (see Table 1), reflecting the difference in the organisation and the size of the HR departments. The interviewees were nominated by the head of HR of each company. In addition, around 20 
Table 1. Characteristics of Organisation Cases

\begin{tabular}{lllll}
\hline \multicolumn{1}{c}{ Characteristic } & \multicolumn{1}{c}{$\begin{array}{c}\text { MNC A: } \\
\text { CoCement }\end{array}$} & MNC B: Colnsure & MNC C: CoTobacco & $\begin{array}{c}\text { Indonesian Public } \\
\text { Institution D: In Monebank }\end{array}$ \\
\hline Industry & Cement & Insurance & FMCG/Tobacco & $\begin{array}{l}\text { Banking and Monetary } \\
\text { Policy and Regulation }\end{array}$ \\
\hline $\begin{array}{l}\text { Current Dominant } \\
\begin{array}{l}\text { Parent Nationality } \\
\text { (\% share, approx.) }\end{array}\end{array}$ & German (65) & Australia (80) & USA (98) & Indonesia \\
$\begin{array}{l}\text { Former Parent } \\
\text { Nationality }\end{array}$ & Indonesia & $\begin{array}{l}\text { Indonesia and its } \\
\text { foreign partners }\end{array}$ & Indonesia & Indonesia \\
\hline Acquisition Year & 2001 & 2007 & 2005 & -- \\
\hline $\begin{array}{l}\text { Number of } \\
\text { Employees }\end{array}$ & $5,000 \mathrm{~s}$ & $\begin{array}{l}300 \mathrm{~s}+5,000 \mathrm{~s} \\
\text { agents }\end{array}$ & $30,000 \mathrm{~s}$ & $6,000 \mathrm{~s}$ \\
\hline
\end{tabular}

informal talks took place on an occasional basis with some of the managers and other employees. Observations were mainly conducted within HR departments to observe the daily lives of the HR actors and their interactions among them and with other colleagues. Documentary studies mainly focused on HR policies, programs, and regulations, also corporate annual reports. Not all organisations allowed the same degree of access to corporate documents. Complementing the interviews within the case organisations, six interviews were added. Four with informants from three consulting firms (Interviewees E1-E4) and two from business schools (Interviewees E5E6). These were to add information regarding the diffusion of HR ideas into the case organisations and within the Indonesian HR field, particularly in Jakarta. The consulting firms were those who previously had consulting projects with the case organisations. While two business schools were chosen considering their significant role in the diffusion of HR ideas. The different data collecting methods and sources enabled data triangulation (Mabry, 2009).

Following the phenomenological tradition (Smith, Flowers \& Larkin, 2009), the interviewees were considered as subjects who actively make sense of their world and ascribe meaning to their everyday experiences (Viney, 1987). They were asked to tell stories about the state of their HR systems and the conditions of their company and external environment. The interviews commenced with a brief explanation about the objective and approach of the study. A broad question asking "What has happened here" (cf. Collis \& Hussey, 2009; Jovchelovitch \& Bauer, 2000) guided all interviews, to produce narratives around the content and process aspects of HR systems configuration within each respondent's firm. The identification of sources of ideas, models, and/or tools that had been brought into the organisations was also included during the conversations. All interviews were audio-recorded, except all interviews at CoTobacco due to the company's policy. In the latter case, interview notes were directly composed afterwards to avoid being forgotten.

Data from the observations were recorded into field notes. Some of documentary data were recorded in the original electronic files, while others were recorded as field notes.

Data analysis was conducted within an interpretiveconstructivist paradigm (Burrel \& Morgan, 1977; Charmaz, 2006; Denzin \& Lincoln, 2005; Schwandt, 1994). It was started when the first data was collected (cf. Birks \& Mills, 2011; Erlandson, Harris, Skipper \& Allen, 1993). The first interview began 
at InMonebank, the comparison case organisation. The coding of data constructed as it accumulated, followed by constant comparisons of data and its interpretation across individual and organisational cases (cf. Charmaz, 2006; Glaser, 1978; Glaser \& Straus, 1967; Suddaby, 2006).

Data analysis was an iterative process and the results of earlier analysis informed subsequent interviews and analyses. It comprised two stages. An early phase of data analysis sought to develop general themes from the data directly after each interview. This includes examining interview transcripts, including interactions with interviewees, field notes, and confirming to the recordings. Memos were developed during the analysis. Relevant literature was also consulted in the effort to increase theoretical sensitivity in data interpretation (cf. Birks \& Mills, 2011; Charmaz, 2006; Glaser, 1978; Glaser \& Strauss, 1967, Strauss \& Corbin, 1990), especially when the findings entered less-anticipated subject areas. As data, categories, and memos were accumulated, logical relationships among the categories were developed by building models that were refined over time during the data collection. At the end of data collection, an early set of categories and their relationships were already established, even though they were revisited during the second stage analysis. As this method combines inductive data analysis and theoretical endorsement from post-analysis literature review, it may be better termed a "quasi-grounded analysis". At the second stage, a full, line by line coding process was conducted on all research documents, particularly focusing on the interview transcripts and audiotaped recording. Coding was done manually, and previous analytical processes and results were maintained, developed or adjusted in this phase.

\section{RESULTS AND DISCUSSION}

Similarities and Differences of Attributes of $H R$ Systems across Cases

This study shows that the phenomenon of similarities in organisational structures and practices exists across the case multinational firms and the comparative case organisation, despite dissimilarities among the organisations. For example, all organisations show a shift from the old model of administrative HR towards a strategic role of HR. Performance-based logic has also become a common language despite not all have fully implemented it. It is surprising to find that CoTobacco and InMonebank have a similar model of HR organisation. This shows how advanced HR ideas or models have penetrated into private firms and selective public organisations. Table 2 presents the similarities and differences.

The similarities of practices suggest a trend of cognitive resemblance towards well-established models or ideas developed in advanced economy contexts that evolved as best practices and later adopted by firms in developing countries like Indonesia. In the case of InMonebank that was commonly regarded as relatively conservative in its management practices. Interviewee D8 of InMonebank perceived that the organisation has to behave like its private counterparts in order to be acknowledged as a good organisation. Aspirations to be like other organisations that have better practices have led organisations such as InMonebank adopting HR ideas or models that are commonly used by top firms.

Despite the similarities, these organisations have also significant differences, particularly when it comes to the detailed elements of HR practices. Performance-oriented management, for example, is widely accepted but with significant differences in the way it is practiced. Among the case organisations, CoTobacco has the most robust performance system, supported by a good range of implementation tools and linked to other HR systems (Table 2). Even CoTobacco itself implemented two difference systems targeting different categories of employees during the transition after acquisition by its multinational parent, although it was moving towards new system transferred from the headquarter. 
Table 2. Similarities and Differences between HR Systems across Cases

\begin{tabular}{|c|c|c|c|c|}
\hline Aspects & CoCement & Colnsure & CoTobacco & InMonebank \\
\hline $\begin{array}{l}\text { Coverage of HR } \\
\text { responsibility }\end{array}$ & $\begin{array}{l}\text { Strategic, incl. } \\
\text { Organisation } \\
\text { Development (OD) }\end{array}$ & Strategic & Strategic & Strategic, incl. OD \\
\hline HR organization & Modified Functional & Functional & (Ulrich) New Roles & (Ulrich) New Roles \\
\hline $\begin{array}{l}\text { Main characteristic } \\
\text { of HR systems }\end{array}$ & $\begin{array}{l}\text { Mainly seniority- } \\
\text { based but in } \\
\text { transition to } \\
\text { performance- based }\end{array}$ & $\begin{array}{l}\text { (Towards) } \\
\text { Performance-based }\end{array}$ & Performance-based & Performance-based \\
\hline Staffing orientation & $\begin{array}{l}\text { Fitting job } \\
\text { requirements }\end{array}$ & $\begin{array}{l}\text { Fitting job } \\
\text { requirements }\end{array}$ & $\begin{array}{l}\text { In search of the best } \\
\text { talent }\end{array}$ & $\begin{array}{l}\text { In search of the best } \\
\text { people }\end{array}$ \\
\hline $\begin{array}{l}\text { Use of outsourced/ } \\
\text { temporary } \\
\text { employees }\end{array}$ & Yes & Yes & Yes & Yes \\
\hline $\begin{array}{l}\text { Focus of human } \\
\text { development }\end{array}$ & $\begin{array}{l}\text { Job-based } \\
\text { competency matrix }\end{array}$ & $\begin{array}{l}\text { Job-based } \\
\text { competency model }\end{array}$ & $\begin{array}{l}\text { Global competency } \\
\text { library }\end{array}$ & $\begin{array}{l}\text { Formally focus } \\
\text { on talent pool, } \\
\text { supported by a } \\
\text { competency model. }\end{array}$ \\
\hline $\begin{array}{l}\text { Performance } \\
\text { management }\end{array}$ & $\begin{array}{l}\text { Single system, with } \\
\text { limited supports and } \\
\text { links to other systems }\end{array}$ & $\begin{array}{l}\text { Single system, } \\
\text { with increasing } \\
\text { awareness of } \\
\text { its links to other } \\
\text { systems }\end{array}$ & $\begin{array}{l}\text { Combined and } \\
\text { complex systems, } \\
\text { with comprehensive } \\
\text { supports and links }\end{array}$ & $\begin{array}{l}\text { Single system, with } \\
\text { increasing link to } \\
\text { other systems }\end{array}$ \\
\hline $\begin{array}{l}\text { Use of talent } \\
\text { management }\end{array}$ & Yes & $\begin{array}{l}\text { Noted but not in } \\
\text { current priority }\end{array}$ & Yes & Yes \\
\hline
\end{tabular}

How can the differences be explained? A variety of sources of ideas that have assisted each firm developing its HR systems may first account for the differences. The characteristics of individual organisations and the ability of HR actors within each organisation to influence the process of translating ideas into internal policies and practices may be another factor. Consulting firms, the HR actors themselves, and the organisation's headquarters are the principal sources or channels of ideas. Previous personal professional education, training, and career contribute to the accumulation of HR knowledge and understanding of the HR actors in the field and impact differently on the translation process. Professional and personal networks also provide benefits in gaining relevant knowledge. Further elaboration on these factors will be presented in the next section, case by case.

\section{HR Systems Configuration Process: Narratives of} the Case Studies

\section{CoCement}

HR systems within CoCement were remodelled as a consequence of strategic restructuring of the company in 1998. The company was founded in 1985 by four Indonesian conglomerates. As the 1997 economic crisis hit Indonesia severely, this company experienced serious financial pressure due to foreign debts incurred for business expansion prior to the crisis (interviewee A1). Under severe financial pressure, CoCement fought for its survival. Interviewees A1, A6, and E3 explained that the company ran a strategic change program from 1998, assisted by a local consulting firm. The case company experienced subsequent changes of ownership from its former shareholders to the Indonesian government in 
1999 and to a German MNC in 2001 that owned 65 percent of its share up until the research was conducted.

Interviewees at CoCement revealed that consultants played a pivotal role in the development of HR systems at CoCement, comparing to other sources of influence, including the multinational parent. Beside the diffusion of ideas from the consulting and parent firms, benchmarking to other companies also played a role in the process. Being under influences of different sources of ideas has however put the HR actors at CoCement into a significant position as channel, mediator, and mixer of ideas. The CoCement case is however a typical case that shows the dominant role of HR consultants (as change agents?) in the configuration of HR systems as part of the strategic renewal of the firm.

The role of the consultants encompasses different stages of the change program. Reflecting on previous years, interviewee A1 stated, "The consultants? They guided us, from the reformulation of vision and mission, strategy, values, style, infrastructure. They guided [us] and provided solutions." The overall strategic framework adopted from the consulting firm was built upon the logic of balanced scorecard, combined with other ideas such as a dualframework organisation and the strategic role of HR. These ideas were considered best practices that worthy to follow. While the actors within CoCement were receivers of cognitive templates provided by the consulting firm, interviewee A7 claimed that the consulting firm also learned a lot from them during the project.

Although many ideas were adopted from the outside, CoCement maintained some of its original ideas. For example, despite adopting performance-based ideas, seniority principle is still used in driving HR policies and practices in areas such as promotion and compensation. CoCement has thus mixed the old and new logics in a decoupled HR framework. The combination of logics was considered appropriate for the company, rather than taking radical change approach. An interviewee speculated that there was an agreement between previous owners, the new parent, and the Indonesian government during the take-over to preserve some of its past characteristics. The decoupling may to any extent hinder the establishment of integrated HR systems, if the elements cannot reach a satisfactory level of balance but this politically fitting of logics might have been an agreeable condition at the point of time.

This case provides an example that extends the dyadic model of influences from headquarters' international strategy and pressures from local government prescribed in rational models (Bartlett \& Ghoshal, 1991, 2000; Doz, Bartlett \& Prahalad, 1991; Schuler, Dowling \& De Cieri, 1993; Taylor, Beechler \& Napier, 1996). The role of a third party, particularly in the form of a consulting firm, should be taken into account. In this case the influence of the parent company and domestic regulative environment existed but tended to be much less significant. The overall mixing or co-existence of different ideas in this case also indicates the role of HR actors of CoCement and of the consulting firm as agencies that carry, channel, and blend different logics.

\section{Colnsure}

CoInsure is another case showing the mixture of influences. This would be best understood by seeing it through the history of the firm. CoInsure seems to have a longer historical root than it is formally indicated. It is formally recognised to be established in 1992 under a joint venture arrangement between a giant Indonesian automotive company and its multinational partner. An external document indicates, however, that it was first established as a wholly owned subsidiary of the Indonesian parent some time before the joint venture. No accessible record regarding the longer historical path is available for this study. In 1997, 
an Australian banking multinational acquired the company, developed a 50/50 partnership arrangement with the Indonesian company. In 2007, the Australian parent bought the majority of share, partnered with another Indonesian company under an 80/20 share arrangement. It was considered, by former parent companies, as an appropriate response to the increasing market demand for more integrated financial services in Indonesia, characterised by a rapid growth in middle income class. The Australian parent was considered to be more capable of nurturing the business, based on experience and capability in the sector and also because of its ongoing expanding business network. This historical trajectory of the firm shows that difference sources of ideas may have had different influences on the firm's HR systems across time.

Even though the Australian parent holds the majority share (80 percent), it was considered by an interviewee that it contributed little in the development of CoInsure's HR systems, particularly in the early phase of the process, following the 2007 acquisition. Interviewee B1 described the early period as perplexing. While losing access to the systems of its former Indonesian parent, no assistance was provided yet by the Australian parent. This is an interregnum period. During the old-partnership arrangement, CoInsure was highly dependent upon the Indonesian parent's HR systems. For example, its training and development programs were part of the parent firm. CoInsure sent its employees to training programs held by the parent. As explained by interviewees B1 and B6, this dependency created difficulties for the HR actors managing the interregnum period. Nevertheless, it is fair to say that CoInsure inherited from its Indonesian parent a few elements of HR practices that have been embedded in its common practices.

The case also displays that there existed a significant role played by individual actors, acting as dominant carriers of, or connectors to, ideas that exist in the wider environment. This has happened particularly after the appointment of a new HR Head. This person has been influential in tackling the transitional situation and also in establishing better communication and coordination with the Australian parent. This person was a management consultant, a former employee of CoTobacco (also a case firm in this research), and once worked for another subsidiary of the former CoInsure's Indonesian parent. This actor has carried an accumulated knowledge acquired from her past working involvements and brought the ideas into CoInsure and developed its HR systems. This is a form of embedded agency, a person who has been walking across organisational boundaries, bringing and blending different ideas. The ideas "at hand" had enabled her to utilise them whenever needed, with a possibility of contextualisation. When asked to clearly identify any exact sources of ideas that were blended into the current CoInsure's HR systems, she vaguely replied, "I could not identify exactly where the knowledge actually came from. What I'm doing now is just responding to the current situation. I really don't know where the ideas come from; I just follow my logics." This case shows how ideas have been embodied in actor's cognitive system and enacted somewhat naturally as the actor confronted with realities. The interviewee considered that the ideas she and her team brought into the configuration process were stimulated by new expectations coming for example from the company's president director.

Other sources of ideas also play a role in the process. At a later phase of the development of the HR systems, inputs were finally received from the Australian parent. This was related to the adoption of service culture and its consequence on employee re-training. Later, CoInsure invited a consulting firm to help it conducting job evaluations and renewing its job grading system compensation policy. In addition to those sources of ideas, a few members of the HR team were involved in networks or associations of HR professionals and of insurance professionals. These professional networks, also other personal networks, were additional sources 
of ideas (e.g. competency standards) for the HR actors in building the HR systems.

\section{CoTobacco}

Although adding no new sources of ideas into those already existing that have been identified so far, the case of Tobacco shows a typical subsidiary of global company that taps into firm specific advantages of its global network while enriched by its own historical path. CoTobacco was a leading firm that was also characterised as a family business before it was taken over in 2005 by its current parent company. Founded by a Chinese immigrant in 1913, the early CoTobacco steadily grew over three generations of the family and became a modern and highly reputable firm, featuring strong characteristics of family business. It was one of Indonesia's top-performing firms and was among the market leaders in tobacco industry. Because of this position, it attracted a US tobacco giant for takeover. The value of the takeover was considered the biggest in the Indonesian investment history showing a strong accumulated market value of the firm.

With around 98 percent share ownership, the influence of the US parent to CoTobacco management systems has been enormous from the start, although CoTobacco had already have good management systems before that. Albeit acknowledged and promised to maintain the former good systems, the US giant exercised great control over its Indonesian subsidiary. Driven by a strong global standardisation strategy, the parent transferred most of HR systems' elements to the subsidiary. Interviewee $\mathrm{C} 10$ admitted that even though the previous systems were good, the adoption of systems from the parent will strengthen CoTobacco. For example, the company recently adopted a global-standardised performance management system from its parent. It carefully, step by step, implement the system, started from top management level. The new system was run alongside the existing system therefore two parallel models were run targeting different employee groups. This was a transition toward a full implementation of the model. From the headquarter, CoTobacco adopted also a new HR organisation, based on Ulrich's (1995) HR new roles framework and made it among the early adopters of the model in Indonesia. All in all, CoTobacco's HR systems have been supported globally coordinated pool of resources within the multinational chain. During the fieldwork period, some elements of the imported systems were put in place, despite the interviewees acknowledged that they were still challenged by the fine tune of the combined systems for a well-coordinated implementation.

This case shows how perceptions of dominant actors at CoTobacco, that the headquarters possess more advanced systems, play a role in the acceptance of the transfer of systems. The subsidiary considered that it better resembles its systems toward those of the headquarters. This implies the greater openness of CoTobacco's HR actors in receiving the vertical transfer of policies and practices from the headquarters, in the expectation that this will later strengthen the firm's market position. The transfer was facilitated by human and non-human carriers, including the intranet resources of the multinational. The dominant human mechanism identified is via international assignments for training, conducted at either the headquarters or the subsidiary.

To a lesser extent, this case also shows there is a mix of ideas from different sources. Systems adopted from the parent firm are implemented gradually and run simultaneously with previous systems CoTobacco had developed. There is thus a mixture of ideas between the old and new models, creating a space for the mediating role for actors to blend the ideas. An interviewees explained that few elements of the systems adopted from the headquarters was also new to the multinational chain. Local implementation at the subsidiary has thus demanded creativity from the local actors, such as the adaptation of the new 
HR organisation, according to interviewee C6. Interviewee $\mathrm{C} 10$ even claimed that CoTobacco could not apply a remuneration practice transferred from the headquarter because it conflicted with its long-term practice and standards common to the Indonesian industrial relations context. This case thus shows that contextual translation or combination of ideas was taking place. In addition to that HR actors at CoTobacco are also reported constantly monitoring what the other leading firms are doing.

\section{InMonebank, the comparative case}

The processes and outcomes of the configuration of HR systems at InMonebank may well be described as a more balanced combination of different sources of ideas, both external and internal to the organisation. Interviewees at InMonebank reported that a series of recent changes within the organisation were directly affected by a change within the regulative environment in Indonesia in 1999. That change was influenced by cognitive and normative schemas in wider institutional realm and in turn affected organisational reality of InMonebank, changing it from an organisation subject to government intervention to a more independent state institution. The change had been engineered for some time, constrained by institutionalised behaviours. InMonebank was highly dependent on the Indonesian government and also subject to political conditions in general. The changes from 1999 onwards, following the 1997 monetary crisis and 1998 political turmoil, increased the momentum for institutional change. Normative expectations and/or pressures from relevant stakeholders increased and led to organisational transformation within InMonebank. Top management set up further change programs, especially on HR systems development.

Two consulting firms were assisting InMonebank's HR actors managing the transformation process since 1999. They supplied ideas for the overall organisational restructuring and especially for the development of HR systems. InMonebank's
HR department has adopted the HR organisation model developed by Ulrich (1995) ever since, signalling it entered the call for HR strategic role to deliver greater value to the organisation. The consulting firms are multinational subsidiaries, so there are connections to some globally distributed ideas.

Apart from the ideas carried by the consultants, InMonebank also benefited from a number of other sources via mimicking behaviour. First from the knowledge brought in by its HR professionals who were sent to study relevant practices at a number of similar institutions in other countries. Interviewees also mentioned that InMonebank conducted several comparative studies to a number of high performing firms in Indonesia. InMonebank has also continued to place its people in external training, development, and educational programs, within and outside Indonesia. The knowledge obtained from the different sources has enabled InMonebank to become more familiar with and easily adopt numerous contemporary management ideas such as strategy-focused, performance-based, and talent management. During an informal talk, an InMonebank staff member said, "With regard to knowledge about modern concepts in $H R$, people here at InMonebank can compete with their counterparts in leading firms." This indicates that this organisation has been successful in its transformation from a former bureaucratic state institution into a professional organisation, as it aspires to be, even though the process of change was still ongoing during the fieldwork.

The adoption and implementation of some external ideas has led HR system of InMonebank to have some similarities to those of the multinational subsidiaries in thus study. An extent of convergence is therefore happening here, related to the search for legitimate knowledge from the outside-in, showing the connectivity of ideas in one place to the other through the connection of actors. Despite the similarities, a characteristic that makes this 
case is markedly different from the other cases is that InMonebank receives no vertical transfer of ideas in the configuration of its HR systems. Unlike the multinational subsidiaries it has no any superior organisation to provide ideas, it however learned from peer organisations.

\section{Discussions}

This article aimed at identifying mechanisms through which HR actors within multinational subsidiaries in Indonesia configure HR systems of their companies. Data from the four case studies show that despite operating in different business settings, there are similarities in major elements of their HR systems. This shows that isomorphism may have been taking place in the configuration process of HR systems, through the mimicking behaviours of HR actors towards systems of other organisations, in their way searching for better systems and improved performance of the firms.

It was shown that $\mathrm{HR}$ actors within the case organisations are connected to other actors outside. This inter-actor connectivity allows them to connect into the realm of $\mathrm{HR}$ ideas that are circulated within and across the wider geographical and institutional contexts of operation of the companies. Based on the case studies we propose a typology of connectivity of actors that play a role in diffusing $\mathrm{HR}$ ideas across organisations and contexts, consisting of three channels of ideas diffusion, namely parent-company, third party organisations, and individual actors. The case of CoTobacco represents the typical parentcompany driven process in which the transfer of elements of HR systems comes predominantly from multinational headquarters. The third partydriven process, which particularly involves the use of consultants, is apparent in all cases at different times but is dominantly represented in the case of CoCement a company that relied heavily on the transfer of ideas from a consulting firm in its process of configuring its HR systems. The third party might be organisations such as rival firms singled out through benchmarking or other players that this study cannot directly empirically identify. The third chanel this study reveals is the role of HR actors themselves as carriers of ideas (cf. Scott, 2008; Zilber, 2002) and as blenders of ideas. The central role of the HR Head of CoInsure is typical of this category. Embedded in the role of actors as channels of ideas diffusion are the different sources of ideas such as previous job experiences, training and educational programs, and personal learning. Our emphasis on the role of individual actors may conversely indicate that the actors themselves may act independently from the existing HR ideas and thus disconfirm isomorphic acts, which is also central to this study. The cases show, however, that actors embody various logics or cognitive models available to them through professional histories and network. The actors may thus directly or indirectly refer to the ideas and easily replicate any of the ideas that are considered appropriate or legitimate for their current or new context. This is comparable to Scott's (2008) cultural-cognitive dimension of institutional effect that shows how internal interpretive processes of individual actors are shaped by shared cultural framework. At the operational level of isomorphic acts, this works through mimetic mechanism, in DiMaggio and Powell (1983)'s term, where actors will tend to follow legitimate models available at a convenient access to the actors. This may also related to Bourdieu's (1983) concept of habitus where choices made by actors are dependent of embodied knowledge and experiences (Grenfell, 2008, p. 52). Thus, this finding still confirms isomorphic acts of actors even though future investigation may be needed and directed toward unpacking this issue to a greater degree.

It is more likely that organisations employ different channels of ideas diffusion simultaneously or subsequently, as particularly seen in the case of InMonebank. The findings of this study echo the isomorphic mechanisms identified by DiMaggio and Powell (1983), namely coercive or dominating mechanisms by headquarters, professional normative mechanisms employed or modelled 
through third parties, and cognitive-cultural mechanisms embodied within actors and other channels

Our cases also show a degree of mix of ideas, between ideas adopted from the outside and those embedded already in the companies old systems or stored as accumulated stock of knowledge in the minds of actors. Based on observations into the case organisations, we contend that different degrees of mixture of ideas have caused differences in detailed implementation of ideas across the firms, albeit common similarities. This adds into the fact of differences in HR systems due to the sources of ideas are different.

\section{Limitations and Implications for Future Research}

Before proceed to implications that can be derived for future research, it is noteworthy that the readers be aware of limitations of the study. First and foremost, findings presented in this work are only a part of a larger study on the configuration of HR systems within multinational context. This implies that not all relevant aspects are presented and discussed fully here in this article. Second, based on an early study, the research had been designed to anticipate that an institutional context plays a role in explaining similarities that may be found across organisations operating in the same institutional context, although they operate in different industries. Third, in relation to that, the study did not intend to explore and explain the effect of industry category on the configuration process.

The research findings provide a foundation for further investigation into the connectivity of actors and ideas, as well as the interactions of institutions and actors, to achieve better understanding of the more detailed mechanisms. Future study should include cognitive processes and factors involved in the process of interpreting and translating institutionalised ideas into particular contexts, in order to understand the phenomenon of similarities and differences of the HR models adopted and implemented in different organisations, including those operating in different organisational fields.

\section{MANAGERIAL IMPLICATIONS}

Bearing the limitations in mind, the research findings have however shed a light on the connectivity of actors and diffusion of ideas that may prove useful for managerial practice and future research, especially in the Indonesian context and in similar developing countries. These results suggest that organisations should enable their HR actors to develop links to other actors and sources of HR ideas. Following the institutional entrepreneurship logic (Boxenbaum \& Jonsson, 2008; Campbell, 2004), this will locate actors such as HR managers in the interstices of different ideas and perspectives, which in turn will enrich them personally and organisationally and may lead to a better mix of ideas being adopted into a firm's existing HR systems.

At the organisational or institutional field level, the interconnectivity of more actors may further benefit the institution of the HR profession, because actors may diffuse more ideas, work on accumulated ideas and thus transform their institution. This is important for institutional contexts in countries such as Indonesia, which is still growing but is mainly characterised by the diffusion and deployment of external ideas, rather than the reconstitution and production of ideas. This also indicates the need for more research in the HR field to provide on-going feedback to the world of practitioners and academics that will stimulate ideas generation.

\section{CONCLUSION}

This study identifies that similarities of elements of HR systems across cases indicate a trend that HR actors adopt ideas that are dominant worldwide or within the Indonesian context, especially among elite groups of companies and organisations such as the case organisations. Our analysis also shows that the evidence of similarities and differences of HR systems in the case multinational companies 
that are joint venture enterprises does not suggest a direct association with factors such as degree of ownership and control, or the home nationality of the multinational, in the diffusion and adoption of ideas into the subsidiaries. We are nevertheless quite convinced by the role played by institutional isomorphic mechanisms through the various forms of connectivity of actors. Giving specific consideration to the behaviour of actors within the case organisations in monitoring what other companies or organisations are doing, even to those in different sectors, we contend that there is a possibility of viral or cross-sectorial diffusion of ideas in the Indonesian context. This supports the notion of a convergence phenomenon among the elite groups of private firms and public organisations. This phenomenon may also apply for other groups, although this could not be confirmed by this study. Here, we justify the importance of the individual actors as connectors, mediators and interpreters of ideas, and their role in receiving and deploying different ideas into their organisations. Our findings point to the dynamic interactions between HR ideas that have been institutionalised at a certain level with the actors at various other levels, including individual actors when they are confronted by differing institutional ideas and must make choices among these ideas.

\section{REFEREN CES}

Arthur, J. B. (1994). Effects of human resource systems on manufacturing performance and turnover. Academy of Management Journal, 37, 670-687.

Arthur, J. B., \& Boyles, T. (2007). Validating the human resource system structure: A levels-based strategic HR approach. Human Resource Management Review, 17(1), 77-92.

Bartlett, C. A., \& Ghoshal, S. (1991). Managing across borders: The transnational solution, Boston, MA: Harvard Business School Press.

Bartlett, C. A., \& Ghoshal, S. (2000). Transnational management: Text, cases, and readings in cross-border management. Boston, MA: McGraw Hill-Irwin.

Becker, B., \& Huselid, M. (1998). High performance work systems and firm performance: A synthesis of research and managerial implications. Research in Personnel and Human Resources Management, 16, 53-101.

Beechler, S., \& Yang, J. Z. (1994). The transfer of Japanese-style management to American subsidiaries: Constraints, and competencies. Journal of International Business Studies, 25(3), 467-491.

Birks, M., \& Mills, J. (2011). Grounded theory: A practical guide. London, UK: Sage.

Bourdieu, P. 1983. The field of cultural production, or: The economic world reversed. Poetics, 12(4-5), 311-356.

Boxenbaum, E., \& Jonsson, S. (2008). Isomorphism, diffusion and decoupling. In R. Greenwood, C. Oliver, K. Sahlin, \& R. Suddaby (Eds.). The Sage handbook of organizational institutionalism (pp. 78-98). London, UK: Sage,

Brewster, C., Mayrhofer, W., \& Smale, A. (2016). Crossing the streams: HRM in multinational enterprises and comparative HRM. Human Resource Management Review, 26(4), 285-297.Burrel, G., \& Morgan, G. (1979). Sociological paradigms and organizational analysis. London, UK: Heinemann.

Campbell, J. L. (2004). Institutional change and globalization. Princeton, NJ: Princeton University Press.

Charmaz, K. (2006). Constructing grounded theory: A practical guide through qualitative analysis. London, UK: Sage.

Hau-siu Chow, I., (2004). The impact of institutional context on human resource management in three Chinese societies. Employee Relations, 26(6), 626-642.

Collis, J., \& Hussey, R. (2009). Business research: A practical guide for undergraduate \& postgraduate students. Hampshire, UK: Palgrave Macmillan.

Czarniawska, B. (2004). Narratives in social science research. London, UK: Sage.

Czarniawska, B., \& Joerges, B. (1996). Travels of ideas. In B. Czarniawska \& G. Sevón. (Eds.). Translating organizational change (pp. 13-48). Berlin, Germany: Walter de Gruyter. 
De Nooy, W. (2003). Field and network: Correspondence analysis and social network analysis in the framework of field theory. Poetics, 31(5-6), 305-327.

Denzin, N. K., \& Lincoln, Y. S. (2005). Introduction: The discipline and practice of qualitative research. In N. K. Denzin, \& Y. S. Lincoln (Eds.). The Sage handbook of qualitative research (pp. 1-32). London, UK: Sage.

DiMaggio, P. J., \& Powell, W. W. (1983). The iron cage revisited: Institutional isomorphism and collective rationality in organizational fields, American Sociological Review, 48, 147-160.

DiMaggio, P. J., \& Powell, W. W. (1991). Introduction. In W. W. Powell \& P. J. DiMaggio (Eds.). The new institutionalism in organizational analysis (pp. 1-38). Chicago: University of Chicago Press.

Doz, Y. L., Bartlett, C. A, \& Prahalad, C. K. (1981). Global competitive pressures and host country demands. California Management Review, XXIII (3), 63-74.

Eisenhardt, K. M. (1989). Building theories from case study research. The Academy of Management Review, 14(4), 532-550.

Elliott, J. (2005). Using narrative in social research: qualitative and quantitative approaches. London, UK: Sage.

Erlandson, D. A., Harris, E. L., Skipper, B. L., \& Allen, S. D. (1993). Doing naturalistic inquiry: A guide to methods. Newbury Park, CA: Sage.

Farndale, E., \& Paauwe, J. (2007). Uncovering competitive and institutional drivers of HR practices in multinational corporations. Human Resource Management Journal, 17(4), 355-375.

Flick, U. (2006). An introduction to qualitative research. London, UK: Sage.

Galaskiewicz, J. \& Wasserman, S. (1989). Mimetic processes within an interorganisational field: An empirical test. Administrative Science Quarterly, 34(3), 454-479.

Flyvbjerg, B. (2006). Five misunderstandings about case-study research. Qualitative inquiry, 12(2), $219-245$.

Glaser, B. G. (1978). Theoretical sensitivity: Advances in the methodology of grounded theory. Mill Valley, CA: Sociology Press.

Glaser, B. G., \& Strauss, A. L. (1956). The discovery of grounded theory: Strategies for qualitative research. Chicago, IL: Aldine Publication.

Greenwood, R., Oliver, C., Sahlin, K., \& Suddaby, R. (2008). Introduction. In R. Greenwood, C. Oliver, K. Sahlin, \& R. Suddaby (Eds.). The Sage handbook of organizational institutionalism (pp. 1-46). London: Sage,

Greenwood, R., Suddaby, R., \& Hinings, C. R. (2002). Theorizing change: The role of professional associations in the transformation of institutionalized fields. Academy of Management Journal, 45(1), 58-80.

Grenfell, M. (2008). Pierre Bourdieu: Key concepts. Stocksfield, UK: Acumen

Guest, D., Conway, N., \& Dewe, P. (2004). Using sequential tree analysis to search for 'bundles' of HR practices. Human Resource Management Journal, 14(1), 79-96.

Hauff, S., Alewell, D., \& Hansen, N. (2016). HR system strength and HR target achievement-towards a broader understanding of HR processes. Human Resource Management. DOI:10.1002/HR.21798.

Huselid, M. A. (1995). The impact of human resource management practices on turnover, productivity, and corporate financial performance. Academy of Management Journal, 38, 635-672.

Jovchelovitch, S., \& Bauer, M. W. (2000). Narrative interviewing [online]. London, UK: LSE Research Online. Available at http:// eprints.lse.ac.uk/2633.

Kaplan, R. S., \& Norton, D. P. (1996). The balanced scorecard: Translating strategy into action. Boston, MA: Harvard Business School Press.

Kepes, S., \& Delery, J. E. (2006). Designing effective HR systems: The issue of HR strategy. In R. J. Burke \& C. L. Cooper (Eds.). The human resource revolution: Why putting people first matters (pp. 55-76). Oxford, UK: Elsevier.

Knight, J. (2000). Suboptimality and social institutions: the relationship between cognition and context. In M. Streit, U. Mummert, \& D. Kiwit (Eds.). Cognition, rationality, and institutions (pp. 11-26). Berlin, Germany: Springer.

Kostova, T., \& Roth, K. (2002). Adoption of an organizational practice by subsidiaries of multinational corporations: Institutional and relational effects. Academy of Management Journal, 45(1), 215-233.

Kostova, T., Roth, K., \& Dacin, T. (2008). Institutional theory in the study of multinational corporations: a critique and new directions. Academy of Management Review, 33(4), 994-1006.

Lepak, D. P. and Snell, S. A. (1999). The Human Resource Architecture: Toward a Theory of Human Capital Allocation and Development, Academy of Management Review, 24(1), 31-48.

Mabry, L. (2009). Case study in social research. In P. Alasuutari, L. Bickman, \& J. Brannen (Eds.). The Sage handbook of social research methods (pp. 214-227). London: Sage.

MacDuffie, J. P. (1995). Human resource bundles and manufacturing performance: Organizational logic and flexible production systems in the world of auto industry. Industrial \& Labor Relations Review, 48(2), 197-221.

Manning C., \& Roesad, K. (2007). The manpower law of 2003 and its implementing regulations: genesis, key articles and potential impacts. Bulletin of Indonesian Economic Studies, 43(1), 59-86.

Martin, J. L. (2003). What is field theory? The American Journal of Sociology, 109(1), 1-49. 
Mizruchi, M., \& Fein, L. C. (1999). The social construction of organizational knowledge: A study of the uses of coercive, mimetic, and normative isomorphism. Administrative Science Quarterly, 44(4), 653 - 83.

Monks, K., \& McMackin, J. (2001). Designing and aligning an HR system. Human Resource Management Journal, 11(2), 57-89.

Myloni, B., Harzing, A. W. K., \& Mirza, H. (2004). Host country specific factors and the transfer of human resource management practices in multinational companies. International Journal of Manpower, 25(6), 518-534.

Paauwe, J. (2004). HR and performance: Achieving long-term viability. Oxford, UK: Oxford University Press.

Powell, W. W., \& Colyvas, J. A. (2008). Microfoundations of institutional theory. In R. Greenwood, C. Oliver, K. Sahlin, \& R. Suddaby (Eds.). The Sage handbook of organizational institutionalism (pp. 276-298). London: Sage.

Pudelko, M., \& Harzing, A. W. (2007). Country-of-origin, localization, or dominance effect? An empirical investigation of HR practices in foreign subsidiaries, Human Resource Management, 46(4), 535-559.

Pudelko, M., \& Harzing, A. W. (2008). The Golden Triangle for MNCs: Standardization towards headquarters practices, standardization towards global best practices and localization, Organizational Dynamics, 37(4), 394-404.

Reay T., \& Hinings, C. R. (2009). Managing the rivalry of competing institutional logics. Organization Studies, 30(06), 629-652.

Riessman, C. K. (2008). Narrative methods for the human sciences. Los Angeles, CA: Sage.

Rupidara, N. S. (2010). Connected actors, connected ideas. Paper presented at the 26th European Group of Organization Studies (EGOS) Colloquium, Lisbon, Portugal (July).

Rupidara, N. S., \& Darby, R. (2017). Institutional influences on HRM in the Asian business environment: the case of Indonesia. Journal of Asia Business Studies, 11(3), 262-277.

Rupidara, N. S., \& McGraw, P. (2008). HR practices and institutional isomorphism among multinational and local companies in Indonesia. Turku, Finland: HR Global 2008 Conference Proceedings.

Rupidara, N. S., \& McGraw, P. (2010). Institutonal change, continuity and decoupling in the Indonesian industrial relations system. Journal of Industrial Relations, 52(5), 613-30.

Rupidara, N. S., \& McGraw, P. (2011). The role of actors in configuring HR systems within multinational subsidiaries. Human Resource Management Review, 21(3), 174-185.Sanders, K., \& Yang, H. (2016). The HRM Process Approach: The Influence of Employees' Attribution to Explain the HRM-Performance Relationship. Human Resource Management, 55(2), $201-217$.

Schuler, R. S., Dowling, P. J., \& De Cieri, H. (1993). An Integrative Framework of Strategic International Human Resource Management. Journal of Management, 19, 419-459.

Schwandt, T. A. (1994). Constructivist, interpretivist approach to human inquiry. In N. K. Denzin \& Y. S. Lincoln (Eds.). Handbook of qualitative research (pp. 118-137). Thousands Oaks, CA: Sage.

Scott, W. R. (2008). Institutions and organizations: Ideas and interests. Thousand Oaks, CA: Sage.

Simandjuntak, D. S. (1999). An inquiry into the nature, causes and consequences of the Indonesian crisis. Journal of the Asia Pacific Economy, 4(1), 171-192.

Smale, A. (2007). Mechanisms of global HR integration in multinational corporations. Acta Wasaensia No. 18, Unpublished doctoral thesis, University of Vaasa, Vaasa, Finland.

Smale, A. (2008). Global HR integration: a knowledge transfer perspective. Personnel Review, 37(2), $145-164$.

Smith, J. A., Flowers, P., \& Larkin, M. (2009). Interpretative phenomenological analysis: Theory, method and research. London: Sage.

Stake, R. E. (1994). Case studies. In N. K. Denzin \& Y. S. Lincoln (Eds.). Handbook of qualitative research (pp. 236-247). Thousands Oaks, CA: Sage.

Stark, S., \& Torrance, H. (2008). Case study. In B. Somekh \& C. Lewin (Eds.). Research methods in the social sciences (pp. 33-40). London: Sage.

Strauss, A. L., \& Corbin, J. (1990). Basics of Qualitative Research: Grounded Theory Procedures and Techniques. Thousand Oaks, CA: Sage.

Suddaby, R. (2006). From the editor: What grounded theory is not. Academy of Management Journal, 49(4), 633-642.

Sumelius, J., Björkman, I., Ehrnrooth, M., Mäkelä, K., \& Smale, A. (2014). What determines employee perceptions of HR process features? The case of performance appraisal in MNC subsidiaries. Human Resource Management, 53(4), 569592.

Takii, S., \& Ramstetter, E. D. (2005). Multinational presence and labour productivity differentials in Indonesian manufacturing, 1975 - 2001. Bulletin of Indonesian Economic Studies, 41(2), 221-42.

Tambunan, T. T. H. (2007). Trade and investment liberalization in the development of small and medium-size enterprises: A perspective from Indonesia. Asia-Pacific Trade and Investment Review, 3(2), 135-146.

Tarmidi, L.T., n.d. Krisis moneter Indonesia: Sebab, Dampak, Peran IMF dan Saran. Retrieved 31 August 2011, from http:// www.bi.go.id/NR/rdonlyres/427EA160-F9C2-4EB0-9604-C55B96FC07C6/3015/bempvol1no4mar.pdf.

Tayeb, M. (1998). Transfer of HRM practices across cultures: an American company in Scotland. International Journal of Human Resource Management, 9(2), 332-358. 
Taylor, S., Beechler, S., \& Napier, N. (1996). Toward an integrative model of strategic human resource management. Academy of Management Review, 21(4), 959-985.

Thee, K. W. (1991). The surge of Asian NIC investment into Indonesia. Bulletin of Indonesian Economic Studies, 27(3), 55-88.

Timberg, T. (2000). Strategy of financing small and medium enterprises in a new economic environment. Paper presented at the Conference on The Indonesian Economic Recovery in Changing Environment. Jakarta: University of Indonesia. Retrieved 22 December 2010, from http:/unpan1.un.org/intradoc/groups/public/documents/APCITY/UNPAN015681.pdf.

Ulrich, D. 1997. HR champions: The next agenda for adding value and delivering results. Boston, MA: Harvard Business Press.

Viney, L. L. (1987). Interpreting the interpreters. Malabar, FL: Robert E. Krieger.

Wright, P. M., \& McMahan, G. C. (1992). Theoretical perspectives for strategic human resource management. Journal of Management, 18(2), 295-320.

Yahiaoui, D. (2014). Hybridization: striking a balance between adoption and adaptation of human resource management practices in French multinational corporations and their Tunisian subsidiaries. International Journal of Human Resource Management, 26(13), 1665-1693.

Yin, R. K. (1989). Case study research: Design and methods. Newbury Park, CA: Sage.

Zilber, T. B. (2002). Institutionalization as an interplay between actions, meanings and actors: The case of a rape crisis center in Israel. Academy of Management Journal, 45(1), 234-254. 